\title{
Transition without transformation: The legacy of Sudan's comprehensive peace agreement
}

Gene Carolan

gene.carolan@tudublin.ie

Follow this and additional works at: https://arrow.tudublin.ie/aaschlawart

Part of the Courts Commons, Dispute Resolution and Arbitration Commons, Law and Society Commons, and the Legislation Commons

\section{Recommended Citation}

Carolan, Gene, "Transition without transformation: The legacy of Sudan's comprehensive peace agreement" (2020). Articles. 37.

https://arrow.tudublin.ie/aaschlawart/37

This Article is brought to you for free and open access by the Law at ARROW@TU Dublin. It has been accepted for inclusion in Articles by an authorized administrator of ARROW@TU Dublin. For more information, please contact arrow.admin@tudublin.ie, aisling.coyne@tudublin.ie,gerard.connolly@tudublin.ie.

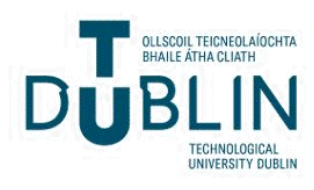




\title{
Transition Without Transformation: The Legacy of Sudan's Comprehensive Peace Agreement
}

\author{
Gene Carolan*
}

\begin{abstract}
In recent years, the transitional justice framework has expanded to include a broader notion of transformative justice, which strives for socio-political reform in addition to legal accountability. Over the course of two civil wars, Sudan has grappled with various attempts at transition and transformation with mixed results. Though the 2005 Comprehensive Peace Agreement brought an end to decades of North-South conflict, South Sudan's subsequent descent into civil war has been characterised by a flawed transition and a lack of any immediate transformative potential.

This paper analyses the Comprehensive Peace Agreement's transitional mechanisms. In doing so, it explores how certain mechanisms frame the 'meta-conflict' about what the conflict is about, and how this can cut off a range of conflict resolution opportunities. It concludes by considering the legacy of the Comprehensive Peace Agreement in contemporary Sudan and South Sudan, and how it might inform the prospective transitions in both countries.

KEYWORDS: Sudan, Comprehensive Peace Agreement, transition, transformation
\end{abstract}

\section{INTRODUCTION}

Despite its recognition as a key pillar of the peacebuilding framework, ${ }^{1}$ the term "transitional justice" continues to elude a precise definition. Transitional justice has been described as 'an entire field of inquiry, embracing a range of postconflict practices, including peacebuilding, reconciliation and restorative justice; and mechanisms such as ad hoc tribunals, specialised courts and indigenous models of justice. In the early 21st century, a 'hybrid' model of peacebuilding emerged, marrying international concerns about human rights norms and accountability to local concerns about agency and autonomy in the postconflict transition. With the decline of liberal interventionism and the failures of that model evident in Libya and Afghanistan, contemporary transitional justice continues to compliment 'bottom-up' approaches to peacebuilding. The field has gradually recognised an emerging concept of 'transformative justice,' which rests on the transformation of social, economic and political

* Technological University Dublin. Email: gene.carolan@tudublin.ie

1 Advisory Group of Experts on the 2015 Review of the United Nations Peacebuilding Architecture, The Challenge of Sustaining Peace, (29 June 2015), para. 39.

2 Ruti Teitel, 'Editorial Note - Transitional Justice Globalized', International Journal of Transitional Justice 2, no. 1 (2008): 1 .

(C) The Author(s) (2020). Published by Oxford University Press. All rights reserved.

For permissions, please email journals.permissions@oup.com 
structures through holistic processes rather than predefined outcomes. ${ }^{3}$ This conceptualisation of justice as not only legal but social has the potential to unleash transformative dynamics at the local level. ${ }^{4}$ These dynamics, in turn, have positive knock on effects in terms of the perceived legitimacy of international peacebuilding initiatives, and the sustainability of that peace. ${ }^{5}$

Sudan is no stranger to the challenges of transitional justice. Over the course of two civil wars, Sudan grappled with various attempts at transition and transformation with mixed results. In 2005, decades of North-South conflict came to an end under the terms of the Comprehensive Peace Agreement (CPA). The CPA boasted many of the features of 'transition': reform of legal and political structures, the security sector; and the redistribution of power and wealth. In the absence of any substantive progress on these issues, the people of South Sudan voted to become an independent state in January 2011. However, independence did not bring about social transformation; quite the opposite. The distribution of political power amongst a North-South elite threatened the transition from the outset, and inhibited genuine transformation in both Sudan and South Sudan. The consequences of this arrangement continue to play themselves out in those countries today.

Accordingly, this paper explores the transitional mechanisms that secured transition but squandered transformation under the CPA. In doing so, it makes a unique contribution to the discourse on political settlements, the transitional/transformative dynamic and the overlap between both frameworks and common peacebuilding strategies. The paper begins by considering transitional justice and its relationship with sustainable peacebuilding. Section III provides a brief introduction to the popular narratives used to frame the North-South conflict in Sudan, and how these relate to the meta-conflict underpinning the CPA. Section IV explores the CPA's transitional mechanisms and considers the spaces where conflict transformation could have occurred. Section V traces the legacy of the CPA to the contemporary transitions in Sudan and South Sudan. To conclude, Section VI surmises the limits of Sudan's transition under the CPA, and argues that a transformative approach can better inform the design and sustainable implementation of transitional mechanisms. Such mechanisms duly comprise an important component of the peacebuilding framework, as is argued in the next section.

\section{TRANSITIONAL JUSTICE AND PEACEBUILDING}

Before asserting the role of peacebuilding infrastructures in transitional justice, it is important to define what is meant by the term. Indeed, "transitional justice" has been used to refer to a wide range of postconflict practices, including peacebuilding, reconciliation and restorative justice. ${ }^{6}$ Rowen has described the 'malleability' of the

3 Paul Gready and Simon Robins, 'From Transitional to Transformative Justice: A New Agenda for Practice', International Journal of Transitional Justice 8, no. 3 (2014): 340.

4 Ibid.

5 Dustin N. Sharp, 'Emancipating Transitional Justice from the Bonds of the Paradigmatic Transition', International Journal of Transitional Justice 9, no. 1 (2014): 150-69, https://doi.org/10.1093/ijtj/iju021; Wendy Lambourne, 'Transitional Justice and Peacebuilding after Mass Violence', International Journal of Transitional Justice 3, no. 1 (2009): 28-48, https://doi.org/10.1093/ijtj/ijn037.

6 Gready and Robins, supra $\mathrm{n} 3$ at 350. 
term as both a strength and a weakness. On the one hand, it can be presented as an alternative to externally imposed, western legal tradition; on the other, its elusive definition means it may be perceived 'as meaning everything, and, therefore, meaning nothing.,

Transitional justice was initially used to label the variety of means through which societies grappled with the abuses of authoritarian regimes in the late 1980s and early 1990 s. $^{8}$ As the decade progressed, the term served as a catch all for a variety of legal processes; including specialised courts, ad hoc tribunals, truth commissions, and other efforts 'to redress mass violence." In 2004, UN Secretary General Kofi Annan defined the UN's normative commitment to transitional justice as embracing 'the full range of processes and mechanisms associated with a society's attempts to come to terms with a legacy of large-scale past abuses....'10 The Secretary General's report noted that transitional justice measures should not be prescribed in isolation, but should be regarded as part of a whole: 'strategies must be holistic, incorporating integrated attention to individual prosecutions, reparations, truth-seeking, institutional reform, vetting and dismissals, or an appropriately conceived combination thereof. ${ }^{, 1}$ Bell notes that the Secretary General's report affected a paradigm shift: a recognition that the concept of transitional justice comprised 'a range of political and social goals beyond accountability. ${ }^{, 12}$

Determining the political and social goals that align with the transitional justice framework remains a subject of scholarly debate, however. As McAuliffe notes, all of the debates in the 'advocacy-cum-policy-oriented' transitional justice literature 'implicitly or explicitly relate to the field's self-identity,' an identity that has become increasingly contested. ${ }^{13}$ Over a very short period of time, the field has raced from debates on peace versus justice and restorative justice versus punitive justice; to questions as to how transitional justice might accommodate broader agendas like socioeconomic justice, everyday security, and women's rights. ${ }^{14}$ A holistic understanding of transitional justice has allowed each of these perspectives to be accommodated, but it has not always produced concrete lessons for policy and practice-a critique advanced most forcefully by McAuliffe. ${ }^{15}$ Instead, holistic processes 'of expanding

7 Jamie Rebecca Rowen, “We Don't Believe in Transitional Justice:” Peace and the Politics of Legal Ideas in Colombia.', Law \& Social Inquiry 42, no. 3 (2017): 640-41.

8 Teitel, supra n 2 at 1; Christine Bell, "Transitional Justice, Interdisciplinarity and the State of the "Field" or "Non-Field”, International Journal of Transitional Justice 3, no. 1 (2009): 7.

9 Rowen, supra $\mathrm{n} 7$ at 624-625.

10 Report of the Secretary-General on the Rule of Law and Transitional Justice in Conflict and Post-conflict Societies, UN Doc. S/2004/616 (2004), 4, para. 8.

11 Report of the Secretary-General on the Rule of Law and Transitional Justice in Conflict and Post-conflict Societies, supra n 10 at 4, para. 8 in Pablo De Greiff, 'Theorizing Transitional Justice', in Transitional Justice: Nomos Li, ed. Melissa Williams, Rosemary Nagy, and Jon Elster (New York: New York University Press, 2012), 31.

12 Bell, supra $\mathrm{n} 8$ at 9.

13 Padraig McAuliffe, 'Reflections of the Nexus between Justice and Peacebuilding', Journal of Intervention and Statebuilding 11, no. 2 (3 April 2017): 250, https://doi.org/10.1080/17502977.2017.1287636.

14 ibid.

15 Pádraig McAuliffe, Transformative Transitional Justice and the Malleability of Post-Conflict States (Cheltenham, UK: Edward Elgar Publishing, 2017); McAuliffe, supra n 13; Lauren Marie Balasco, 
the interdisciplinary spaces within transitional justice' have become divorced from the actual study of post-conflict ecologies. ${ }^{16}$

This article does not seek to lend credence to McAuliffe's critique by arguing that peacebuilding activities constitute an important component of the transitional justice framework. Rather, it is submitted herein that the link between the two is central to understanding McAuliffe's 'post-conflict ecologies.' Though transitional justice 'has not generally been conceived as an analytical category for understanding sustainable peacebuilding, ${ }^{, 17}$ the two are to some extent mutually constitutive of one another. In the early 1990s; transitional justice, multiparty democracy, and free markets emerged as pillars of a liberal peacebuilding project that had the democratic state as its endpoint. ${ }^{18}$ Transitional justice-with its commitment to the rule of law and respect for basic civil and political rights-comprised an important stepping stone towards this overall goal. ${ }^{19}$ However, the liberal peacebuilding project often manifested as a statecentred paradigm that prioritized institutional change over local and particular needs. ${ }^{20}$ The frequent prescription of state-centred peacebuilding initiatives was based on the analysis that conflict recurrence is linked to State capacity. ${ }^{21}$ However, State capacity cannot be built in isolation from the society which it must serve. ${ }^{22}$ Indeed, Gready and Robins contend that the perceived equivalence of statebuilding and peacebuilding 'has seen transitional justice practice... fail in fragile states. ${ }^{23}$ Liberal peacebuilding strategies were often simplified in their design, favouring professional expertise and best practice over local customs and civil society structures. ${ }^{24}$ As a result, affected populations were frequently left with paper institutions that were divorced from the societies in which they function, unable to provide for everyday

'Locating Transformative Justice: Prism or Schism in Transitional Justice?', International Journal of Transitional Justice 12, no. 2 (1 July 2018): 368-78, https://doi.org/10.1093/ijtj/ijy004.

16 McAuliffe, supra $\mathrm{n} 13$ at 250.

17 Lambourne, supra $\mathrm{n} 5$ at 29.

18 Stef Vandeginste and Chandra Lekha Sriram, 'Power Sharing and Transitional Justice: A Clash of Paradigms?', Global Governance 17, no. 4 (2011): 489-505; Gready and Robins, supra n 3.

19 Vandginste and Sriram, supra n 18; L. J. Laplante, 'Transitional Justice and Peace Building: Diagnosing and Addressing the Socioeconomic Roots of Violence through a Human Rights Framework', International Journal of Transitional Justice 2, no. 3 (17 October 2008): 331-55, https://doi.org/10.1093/ijtj/ijn031; De Greiff, supra n 11.

20 Sharp, supra n 5 at 163; Gready and Robins, supra n 3.

21 Cedric de Coning, 'From Peacebuilding to Sustaining Peace: Implications of Complexity for Resilience and Sustainability', Resilience 4, no. 3 (2016): 173, https://doi.org/10.1080/21693293.2016.1153773; Aleksi Ylönen, 'Reflections on Peacebuilding Interventionism: State and Nationbuilding Dilemmas in Southern Sudan (2005 to the Present)', Global Change, Peace \& Security 28, no. 2 (3 May 2016): 213-23, https://doi.org/10.1080/14781158.2016.1159548; Roland Paris and Timothy D. Sisk, eds., The Dilemmas of Statebuilding: Confronting the Contradictions of Postwar Peace Operations, Security and Governance Series (London; New York: Routledge, 2009); Ashraf Ghani and Clare Lockhart, 'Writing the History of the Future: Securing Stability through Peace Agreements', Journal of Intervention and Statebuilding 1, no. 3 (1 November 2007): 275-306, https://doi.org/10.1080/17502970701592249; Advisory Group of Experts, supra $n 1$.

22 Cedric de Coning, John Karlsrud, and Paul Troost, 'Towards More People-Centric Peace Operations: From "Extension of State Authority" to "Strengthening Inclusive State-Society Relations", Stability: International Journal of Security \& Development 4, no. 1 (2015): 1-13.

23 Gready and Robins, supra n 3 at 341-342.

24 Kieran McEvoy, 'Beyond Legalism: Towards a Thicker Understanding of Transitional Justice', Journal of Law and Society 34, no. 4 (2007): 424. 
security and welfare requirements. Many of these critiques manifest themselves in the Sudanese transition under the CPA, as will be detailed below.

In the years since, critiques of transitional justice strategies have come to mirror many of the charges levelled against liberal peacebuilding activities:

$[\mathrm{T}]$ hat they have been externally driven, being planned and implemented in a 'top-down' state-centric manner that tends to marginalize local values and practices, and that they are presented as neutral and apolitical solutions to highly contested questions. ${ }^{25}$

Transitional justice fits this pattern insofar as it prioritizes individual acts of violence and violations of civil and political rights over 'chronic structural violence and unequal social relations. ${ }^{26}$ Populations affected by legacies of violence have limited input into the design and the purpose of transitional justice mechanisms; and often participate in highly prescribed ways: 'as witnesses, as defendants or through the giving of testimony.' ${ }^{27}$ The tendency to prioritize formal institutions and privileged discourses - such as law and the language of human rights - can potentially exclude affected populations and empower elites, leading to a situation where justice is a concept claimed on behalf of victims rather than by victims themselves. ${ }^{28}$ In contrast, local input and popular access to transitional justice processes offer opportunities to challenge power relations at both the local and international levels. The resulting benefits 'trickle up' the peacebuilding infrastructure in a 'bottom-up' inversion of previous peacebuilding strategies. ${ }^{29}$

This inversion of typical peacebuilding models is reflective of the transformative turn in transitional justice scholarship. ${ }^{30}$ Transformative justice can be distinguished from transitional justice insofar as it looks beyond the injustices related to the consequences of conflict, to the neglect of the injustices implicit in the causes and symptoms of the conflict. ${ }^{31}$ Transformative justice's mandate duly extends to socioeconomic rights, everyday security, and other markers of positive peace; in addition to the violations of physical, civil and political rights that frequently characterise post-conflict settings. ${ }^{32}$ Gready and Robins describe transformative justice as a balance of principle and pragmatism, where the need to pursue wrongdoers must be offset against whatever best institutionalizes peace and effective service delivery. Accordingly, socioeconomic rights should be employed as a means to address local needs, and to challenge intersections between economics and power. A transformative approach must also recognise that conflict that appears new is often 'rooted in

26 Gready and Robins, supra n 3 at 342.

27 Ibid at 343.

28 Ibid at 343 [emphasis added]; McAuliffe, supra n 15.

29 Sharp, supra $\mathrm{n} 5$ at 164.

30 McAuliffe, supra n 15.

31 Rama Mani, 'Balancing Peace with Justice in the Aftermath of Violent Conflict', Development 48, no. 3 (September 2005): 27, https://doi.org/10.1057/palgrave.development.1100165. 
ongoing experiences of social marginalization, political exclusion and economic exploitation. ${ }^{, 33}$ A transformative approach will be committed to uprooting these cycles of violence and preventing future conflict. A transformative lens is thus particularly appropriate for a case study of Sudan's transition.

Gready and Robins argue that transformative justice should be locally driven, 'because such change is most likely to be informed by the local and particular needs of people in communities where legacies of violence play out. ${ }^{34}$ Accordingly, a transformative approach will emphasise local agency and resources in the design, implementation and evaluation of transitional mechanisms. Local input is also central to challenging the socio-political and economic structures that may have characterised the state-society relationship hitherto. A transformative approach duly requires a critical analysis of participation in transitional justice mechanisms: a focus on 'whose voice is heard and which organisations gain a seat at the table. ${ }^{35}$ Where a transformative approach is employed rigorously, it is potentially emancipatory: postconflict transition not only checks and punishes mass violence, but responds to the needs of the population as identified by the population, from below. ${ }^{36}$ In upending existing social structures, transformative justice seeks to unleash the social dynamics that can fuel and sustain transformation: societal transformation is both the starting point and the intended result. ${ }^{37}$ Identifying the sites where transformation can take place is thus central to achieving justice in post-conflict ecologies defined by a flawed transition.

Transformative justice is not beyond the critiques that have plagued transitional justice in the past, however. Transformative justice scholarship has been criticised for stacking the transitional justice framework with further normative expectations, and expanding its interdisciplinary spaces beyond the field's remit. ${ }^{38}$ McAuliffe questions whether the transition from war to peace is actually an appropriate transformative constitutional moment, as some of the scholarship suggests; or whether behavioural norms have come to dictate the policy options available to international and domestic actors. Furthermore, much of the transitional/transformative literature presents a reductive dyadic, relationship between domestic and interactional actors which obscures a clear vision of where power and influence reside in existing societal structures. ${ }^{39}$ What is missing is a transformative analysis that can disaggregate the international, the national, and the local; interrogate the bargaining processes that limit the scope of transitional justice strategies in practice; and link these findings to a practicable theory of change that furthers 'the transformative turn as an intellectual endeavour. $^{40}$

36 David Roberts, Liberal Peacebuilding and Global Governance: Beyond the Metropolis (London; New York: Routledge, 2013); in Gready and Robins, supra $n 3$.

37 Lambourne, supra n 5; Balasco, supra n 15; Gready and Robins, supra n 3.

38 Balasco, supra n 15.

39 McAuliffe, supra n 13 at 252.

40 McAuliffe, supra n 15 at 167; McAuliffe supra n 13. 
Such an ambition may be beyond the conceptual scope of this paper. Where transitional justice mechanisms are the focus of a transformative analysis, significant conceptual challenges present themselves. First, such an analysis may neglect the political factors that might help or hinder transformation prior to the design or implementation of the transitional justice mechanism. Second, the use of transformative justice as a means of evaluating transitional justice hinders the development of transformative justice as a field in its own right: 'one that may extend beyond transitional justice. ${ }^{41}$ However, a transformative framework does allow a critical approach to analyzing transitional justice mechanisms by revealing typologies of participation. ${ }^{42}$ That is exactly the aim of this paper. A critical retrospective of the CPA reveals how it prescribed a particular typology of participation that would frame the Sudanese transition. In exploring the agreement's transitional mechanisms, this paper seeks to identify where the Sudanese transition was contested; how the transition neglected other power struggles; and how it failed to deliver a positive vision of transformative justice. A case study of Sudan may also free the potentially transformative aspects of the CPA from their 'particular spaces, times and issues of focus, ${ }^{43}$ thereby distilling aspects of the transformative justice framework for future application.

\section{THE NORTH-SOUTH CONFLICT IN SUDAN}

While the North-South conflict represented a prolonged and violent expression of political grievance, it 'was just one part of a broader web of conflicts involving competing claims... to land, water, natural resources, political power or cultural identity. ${ }^{44}$ Conflict has plagued Sudan for decades, and the conflicts in Darfur, South Kordofan and Blue Nile share many of their root causes with that of the NorthSouth conflict including religious and racial discrimination, and economic and political marginalisation. This paper adopts the North-South conflict as its exclusive focus, however. This reflects the central government's 'piecemeal regional approach' to peacemaking, which prevented Sudan's various rebel groups from uniting against Khartoum's privileged position. ${ }^{45}$ Furthermore, the North-South peace process spanned 40 years, thus creating the longest paper trail of conflict resolution instruments in Sudan. As the most fruitful product of the North-South process, the CPA became the legal standard to which other rebel groups aspired. ${ }^{46}$ The CPA thus represents an attempt to perfect the transitional justice mechanisms that were repeatedly prescribed during that time.

41 Balasco, supra n 15.

42 Gready and Robins, supra n 3 at 357.

43 Ibid at 359.

44 Mark Simmons and Peter Dixon, 'Introduction', in Peace by Piece: Addressing Sudan's Conflicts, ed. Mark Simmons and Peter Dixon (Accord Conciliation Resources, 2006), 6.

45 Julian Thomas Hottinger, 'The Darfur Peace Agreement - Expectations Unfulfilled', in Peace by Piece: Addressing Sudan's Conflicts, ed. Mark Simmons and Peter Dixon (Accord Conciliation Resources, 2006), 47.

46 Ibid. at 48. Hottinger alleges that rebel groups in Darfur 'expected a comprehensive agreement of their own,' but this has proven impracticable under the exclusive nature of the CPA's power-sharing provisions. 
The debate on the causes of Sudan's civil wars is - much like the Sudanese conflicts themselves-'divisive and far from settled. ${ }^{, 47}$ The effects of religious differences, economic exploitation and colonial intervention have all played their part in fuelling the conflict, 'but none, by itself, fully explains it. ${ }^{48}$ Prior to independence, Britain and Egypt administered the Sudan as two separate regions, 'with political power and control of the country's extensive natural resources, as well as decisions over education, policy, language and cultural identity, centered in the north. ${ }^{49}$ On the eve of Sudanese independence, the country existed as two wholly different economic systems: one 'was relatively well developed and the other was one of the least developed parts of the British global empire. ${ }^{50}$ This institutionalized pattern of underdevelopment and neglect would haunt Sudan for its entire 20th century history.

Following independence, power was centred in the hands of a north Sudanese, Arab-Islamic elite whose vision rarely extended beyond its own power base in the golden triangle between the Blue and White Niles. The Arab-Islamic identity was employed as a central tenet of nation building, and institutionalized policies of Arabization and Islamization became a feature of the new Sudanese republic. ${ }^{51}$ However, far from creating an ethnically distinct Islamic nation in Sudan, these policies often had the opposite effect: 'they created a fierce reaction which in many ways solidified and cemented identities along ethnic and cultural lines. . 52 Southern leaders soon realized that the chronic underdevelopment and cyclical violence in the south was the product of the northern elite's efforts to culturally dominate the region. Faced with inequalities in political and economic opportunity, the African, Christian and Animist South took up arms against the Sudanese state; initially as a myriad coalition of tribes and later, under John Garang's Sudan People's Liberation Movement/Army (SPLM/A). El-Battahani defines the resulting conflict as a contest between the centre and the periphery arising from 'economic, resource-based, ethnic, cultural, religious and international' concerns, all of which were exacerbated by the centralized government's 'crisis of legitimacy and its utility as a vehicle for economic exploitation. 53

47 Luka Biong Deng, 'The Sudan Comprehensive Peace Agreement: Will It Be Sustained?', Civil Wars 7, no. 3 (2005): 245, https://doi.org/10.1080/13698280500423924.

48 Douglas H. Johnson, The Root Causes of Sudan's Civil Wars, African Issues (Oxford: Currey, 2007), 1-2; in Amel Aldehaib, 'Sudan's Comprehensive Peace Agreement Viewed through the Eyes of the Women of South Sudan', Institute for Justice and Reconciliation Fellows Programme Occasional Paper, (2010), 3.

49 Dan Connell, 'Peace in Sudan Prospect or Pipe Dream?' Middle East Report, no. 228 (2003): 3.

50 Andrew S. Natsios, Sudan, South Sudan, and Darfur: What Everyone Needs to Know (New York/Oxford; Oxford University Press, 2012), 27.

51 Abel Alier, Southern Sudan: Too Many Agreements Dishonoured, 2nd edn, Sudan Studies Series 13 (London: Ithaca Press Reading, 1992), 24. Christian missionary activities were prohibited, except under license, and Muslim schools sprang up in both urban and rural areas. Arabic became the language of instruction in schools, and southern public servants were made redundant for their lack of Arabic. A recruitment ban for the police and prison forces came into effect in the south, and vacant places in these sectors were filled with recruits from the north.

52 Anders Breidlid, 'The Role of Education in Sudan's Civil War', Prospects 43, no. 1 (2013): 39.

53 Atta el-Battahani, 'A Complex Web - Politics and Conflict in Sudan', in Peace by Piece: Addressing Sudan's Conflicts, ed. Mark Simmons and Peter Dixon (Accord Conciliation Resources, 2006), 10. 
Even prior to the North-South negotiations that culminated with the CPA, commentators noted that confronting the root causes of the civil war would necessitate a radical reframing of Sudanese society. ${ }^{54}$ As Connell surmises, the conflict did not lend itself to simple solutions because every issue carried significant political, cultural and economic value, 'from the definition of what it means to be a citizen of Sudan to who controls the country's newfound oil wealth. ...55 Sudan has thus been the site of two conflicts: the North-South conflict itself, and what McGarry and O'Leary call the 'meta-conflict' - the contest to define what the conflict is about. ${ }^{56}$ This 'metacontestation' is central to conflict resolution efforts, 'because each meta-conflict position presupposes a different set of solutions to the conflict....57 The state's dominance over this 'meta-conflict' can be readily observed in the peace process, which has repeatedly neglected the legitimate grievances of the southern peoples. Both the Addis Ababa Agreement (1972) and the Sudan Agreement (1997) failed to meaningfully address the role of religion and wealth in the North-South conflict, and both remained subject to Khartoum's unilateral implementation. ${ }^{58}$ The southern movement's inability to contest the 'meta-conflict' can duly be linked to its failure to secure its political aspirations over time. It was not until 1998, when Khartoum ceded control of negotiations to the Intergovernmental Authority on Development (IGAD), that the parties began to take meaningful steps towards peace.

Initially, progress was slow. Negotiations in Nairobi in July 1999 made no substantial progress, nor did two further meetings over the course of 2000 . It was only when the United States shifted its policies towards Sudan that the IGAD process began to make headway. Following the $9 / 11$ attacks in 2001, the administration of George W. Bush stepped up its effort to resolve the North-South conflict, with President Bush telephoning President Bashir a dozen times during the negotiations that culminated with the CPA. ${ }^{59}$ Domestic politics also favoured peace at this time. The position of pragmatists and moderate Islamist elements in Khartoum encouraged compromise with the SPLM/A in return for normalised relations with the international community, particularly the US. The US also had a significant influence as part of the Troika, in partnership with the United Kingdom and Norway. The chief mediator in the IGAD process, General Lazaro Sumbeiyo, used the Troika to break deadlock in negotiations, and the Troika later resolved disputes in the interim period that followed the CPA. ${ }^{60}$

Taisier Mohamed Ahmed Ali and Robert O. Matthews, Civil Wars in Africa: Roots and Resolution (Ithaca/ Montreal; McGill-Queen's University Press, 1999), 217.

55 Connell, supra n 49 at 3.

56 John McGarry and Brendan O’Leary, Explaining Northern Ireland: Broken Images (Oxford/Cambridge: Blackwell, 1995); in Christine Bell, 'Contending with the Past: Transitional Justice and Political Settlement Processes', in Justice Mosaics: How Context Shapes Transitional Justice in Fractured Societies, ed. Roger Duthie and Paul Seils (NYC: International Center for Transitional Justice, 2017), 91.

57 Bell, supra n 56 at 91.

58 Gene Carolan, 'Statebuilding in the Peace Agreements of Sudan and South Sudan,' Journal ofIntervention and Statebuilding, (3 January 2020): 1-24, https://doi.org/10.1080/17502977.2019. 1703492.

59 Natsios, supra n 50.

60 Johan Brosché and Allard Duursma, 'Hurdles to Peace: A Level-of-Analysis Approach to Resolving Sudan's Civil Wars', Third World Quarterly 39, no. 3 (4 March 2018): 560-76, https://doi.org/10.1080/ 01436597.2017.1333417. 
Despite this international dimension, the mediators do not appear to have given much thought to the constituencies that were admitted to the IGAD process. The CPA was predicated on an equitable but exclusive distribution of power between the National Congress Party and the SPLM/A, both of which represented a minority of the Sudanese population. However, John Garang's vision of a secular Sudan in which religion was a personal preference had long resonated with liberal politicians in the US, and this helped to establish the SPLM/A as the legitimate representative of southern aspirations internationally. ${ }^{61}$ As a result, the mediators do not appear to have given much thought to how other constituencies or dimensions, such as gender, were represented in the CPA. ${ }^{62}$ Chief mediator Sumbeiyo did attempt to raise the prospect of a pan-Sudanese process that would address the conflicts in east Sudan and Darfur, but the central government would not allow it: 'Every time I tried to raise it they said, "oh, you want to come and resolve all our conflicts? Come to Darfur, come to Eastern Sudan, we have enough problems. Come to the north; we have a lot of problems!"'63 Despite the modest efforts of the mediators, the CPA was more of a product of national and international political dynamics than the result of an international transitional or transformative agenda.

The CPA's exhaustive detail provided an initial burst of momentum that secured a functioning regional government of South Sudan (GoSS) in the early days of the peace process. Immediately thereafter, progress began to stall. Disputes over wealth sharing and the Sudanese military's withdrawal from South Sudan caused the CPA's power sharing provisions to break down in 2007. Though the dispute was resolved by the end of that year, nationwide general elections scheduled for July 2009 did not occur until April 2010. As progress slowed, South Sudan's 2011 referendum on selfdetermination came to be seen as the CPA's 'centre-piece,' and the costs of hard engagement in a transformative project became much more obvious than the costs of secession. ${ }^{64}$ The people of South Sudan duly voted for secession in January 2011, and on 9 July, South Sudan became an independent state. In the next section, this paper examines how the CPA's transitional mechanisms affected that outcome.

\section{TRANSITION AND TRANSFORMATION UNDER THE CPA}

The CPA featured many of the transitional justice and statebuilding processes that are common to liberal peacebuilding interventions. The agreement prescribed power and wealth sharing; national and international human rights protections; and reform of the security sector, the judiciary, and the constitution in order to give effect to the

61 Cirino Hiteng Ofuho, 'Negotiating Peace - Restarting a Moribund Process', in Peace by Piece: Addressing Sudan's Conflicts, ed. Mark Simmons and Peter Dixon (Accord Conciliation Resources, 2006); John Young, The Fate of Sudan: The Origins and Consequences of a Flawed Peace Process (London; New York: Zed Books, 2012).

62 Anne Itto, 'Guests at the Table? The Role of Women in Peace Processes', in Peace by Piece: Addressing Sudan's Conflicts, ed. Mark Simmons and Peter Dixon (Accord Conciliation Resources, 2006).

63 Mark Simmons and Peter Dixon, 'The Mediator's Perspective - An Interview with General Lazaro Sumbeiyo', in Peace by Piece: Addressing Sudan's Conflicts, ed. Mark Simmons and Peter Dixon (Accord Conciliation Resources, 2006), 37.

64 Edward Thomas, 'Against the Gathering Storm - Securing Sudan's Comprehensive Peace Agreement' (Chatham House, 2009), 6, https://www.ciaonet.org/attachments/13800/uploads. 
agreement's provisions. ${ }^{65}$ In this particular respect, the CPA may be tentatively regarded as a transitional justice instrument, insofar as it sought to break with a legacy of centralized, authoritarian government and restricted civil and political life. However, the agreement was virtually silent on the issue of accountability, and in places, it explicitly prevented it. The agreement's power-sharing provisions ensured that senior members of the ruling National Congress Party and the SPLM/A could shield themselves from any accountability processes through executive action; for example, by appointing or removing officials in Sudan's judicial system. Indeed, the National Congress Party was able to use its domination of the national government-as guaranteed by the CPA - to repeatedly resist any calls for the surrender of (then) president Omar Al Bashir to the International Criminal Court. ${ }^{66}$ Al Bashir further politicised the International Criminal Court indictment in order to consolidate his grip on power and to foment hostility to the CPA in the years following South Sudan's independence. ${ }^{67}$ Given this flagrant denial of justice, it is difficult to describe the CPA as an instrument of transitional justice.

That said, the CPA does provide a blueprint towards a limited concept of justice. The agreement was even premised on a transformative vision of positive peace, pledging to replace war in Sudan 'not just with peace, but also with social, political and economic justice which respects the fundamental human and political rights of all the Sudanese people. ${ }^{68}$ The CPA's provisions on wealth-sharing and socioeconomic rights supported this vision in theory, but they could not guarantee the political will to orient these provisions towards transformative ends. ${ }^{69}$ Such transformative change requires an attitudinal shift that transitional justice mechanisms 'can only ground but not produce. ${ }^{70}$ As Balasco duly warns, transformative justice advocates should be careful not 'to assign transformative justice tasks to transitional justice mechanisms, because these mechanisms may be incapable of delivering such transformation.' This is an important point to bear in mind as this article proceeds to its central analysis.

While the CPA did affect a transformative shift in the North-South relationship, in doing so it maintained a state-centric approach that prioritized institutional change. The agreement provided for a complex transitional infrastructure that gave the SPLM/A a joint role in implementing the agreement. As such, it is the first truly bilateral instrument to emanate from the North-South conflict. The parties could

65 The Comprehensive Peace Agreement between the Government of the Republic of Sudan and the Sudan People's Liberation Movement/Sudan People's Liberation Army (Comprehensive Peace Agreement), 9 January $2005 \quad$ http://peacemaker.un.org/sites/peacemaker.un.org/files/SD_060000_The \%20Comprehensive\%20Peace\%20Agreement.pdf (accessed 19 August 2017). Chapter II, Part I, Article 1.6.1 obliges the Sudanese state to comply with the international legal framework on political, economic, social, cultural and human rights.

66 Vandeginste and Sriram, supra n 18.

67 Mattia Cacciatori, 'When Kings Are Criminals: Lessons from ICC Prosecutions of African Presidents', International Journal of Transitional Justice 12, no. 3 (2018): 386-406.

68 Comprehensive Peace Agreement, supra n 65 at Chapter I, Part A, Article 1.5.2.

69 Padraig McAuliffe, 'Dividing the Spoils: The Impact of Power Sharing on Possibilities for Socioeconomic Transformation in Postconflict States', International Journal of Transitional Justice 11, no. 2 (July 2017): 197-217, https://doi.org/10.1093/ijtj/ijx004.

70 De Greiff, supra n 11 at 52 . 
settle disputes pertaining to the agreement through the senior political decision making body, the Political Commission. Joint Military Committees served as forums for communication and dispute resolution in the tense postconflict security environment. Notably, both the Political Commission and the Joint Military Committees were required to reach their decisions by consensus. ${ }^{71}$ Failing resolution at this level, disputes among the various peacebuilding organs could be referred up to the Constitutional Court of Sudan, which had ultimate interpretive authority over the CPA. This level of inclusion was hitherto unprecedented in Sudan's history of conflict resolution.

While these mechanisms did succeed in transitioning the North-South conflict to a postconflict state, the framing of the 'meta-conflict' under the CPA cut off the range of mechanisms and constituents necessary to affect a transformative change in Sudan's political culture. The CPA correctly identified the North-South conflict as a consequence of an exploitative centre-periphery relationship. However, it sought to resolve that conflict by coopting peripheral southern elites into the centre. Even in 2010, a multi donor evaluation had identified a disconnect between regional and local government structures in South Sudan, and warned against duplicating the Khartoum-South relationship in South Sudan by placing ' $[\mathrm{t}]$ )o much focus on Juba. ${ }^{, 72}$ The highly devolved GoSS envisioned on paper was overly reliant on formal institutions in practice, despite contemporaneous claims that local government would be central to securing peace in South Sudan. ${ }^{73}$ Indeed, anxieties about local issues such as land ownership led to conflict in the South, with interethnic violence actually increasing after the conclusion of the CPA. ${ }^{74}$ Many of the subsequent issues that plagued South Sudan's postconflict transition can be traced back to the way that the North-South meta-conflict was framed in the CPA. That the CPA failed to confront these inequitable structures of power in Sudanese society is a denial of transformative justice, and largely explains why cycles of violence have continued to regenerate in South Sudan.

By framing Sudan's meta-conflict along a North-South axis and distributing power accordingly, the CPA allowed the National Congress Party and the SPLM/A to consolidate their power to the detriment of the myriad constituents that comprised Sudanese society. ${ }^{75}$ The CPA's provisions on 'the three areas' best illustrate how the CPA's transitional mechanisms did not extend to other marginalised constituents. The CPA prescribed particular arrangements for Sudan's three areas; Abyei, South Kordofan, and Blue Nile; each of which were supposed to be subject to the will of the people of in those regions. However, this never came to be. The three areas were not consulted as the CPA promised, yet the peace process moved forward

71 Comprehensive Peace Agreement, supra n 65 at Annexure I, Part I, Articles 14.4 and 14.6.4, respectively.

72 Jon Bennett et al., 'Aiding the Peace: A Multi-Donor Evaluation of Support to Conflict Prevention and Peacebuilding Activities in Southern Sudan 2005-2010' (United Kingdom: ITAD Ltd, December 2010), xix.

73 Adam Branch and Zachariah Cherian Mampilly, 'Winning the War, but Losing the Peace? The Dilemma of SPLM/A Civil Administration and the Tasks Ahead', The Journal of Modern African Studies 43, no. 1 (2005): 1-20.

74 Thomas, supra n 64 at 28.

75 Alex de Waal, 'Peace and the Security Sector in Sudan, 2002-11', African Security Review 26, no. 2 (2017): 182, https://doi.org/10.1080/10246029.2017.1297582. 
regardless. When South Sudan voted to secede from the Republic of Sudan in January 2011, fighting broke out in South Kordofan and the national government forcibly seized Abyei. The unrest spread to Blue Nile several months later, and the conflict remains unresolved to date. Clearly the CPA's provisions have done little to foment the transformative dynamics necessary to challenge Khartoum's systematic neglect of these areas.

The CPA's provisions on wealth sharing are also implicated in this framing of the North-South meta-conflict. As with most of its key terms, the CPA's wealth sharing provisions were dependent on national, formal institutions that were divorced from the everyday needs of ordinary people throughout Sudan. The agreement's statecentric provisions redistributed wealth 'so as to enable each level of government to discharge its legal and constitutional responsibilities and duties. ${ }^{, 76}$ The provision of specific formulae for the redistribution of oil revenues was central to forcing the issue of southern self-determination, given Khartoum's reluctance to address the more contentious aspects of the CPA towards the end of the interim period. However, by linking wealth redistribution to national level institutions, the CPA inhibited any sort of meaningful bottom-up initiative that could challenge some of Sudan's structures of economic injustice. ${ }^{77}$ Instead, the CPA inadvertently reproduced Khartoum's kleptocratic system of political patronage in which every aspect of the oil business intersects with a web of divisive politics. ${ }^{78}$ This has traditionally allowed Khartoum to maintain its privileged position at the centre by admitting or buying off any stakeholders with sufficient political clout. Since the conclusion of the CPA in 2005, South Sudan has functioned as a system 'even less regulated and no less brutal than its northern counterpart, ${ }^{, 79}$ with political and armed opposition coopted through admittance to 'the big tent' at the political centre. When oil revenues were cut off owing to a dispute with the Republic of Sudan in January 2012, this strategy was no longer tenable, and the resulting political tensions led to civil war.

Ironically, attempts to resolve the South Sudanese conflict to date have adopted the CPA's strategy of dividing power amongst the political elite. Both the 2015 Agreement on the Resolution of the Conflict in the Republic of South Sudan and its revitalised 2018 counterpart sought to resolve the conflict by admitting the principal armed actors to privileged positions of power and wealth. The Sudanese experience of transition suggests that such measures are conducive to neither sustainable peace nor transformative justice. In order to affect transformative justice in South Sudan, wealth sharing must be locally oriented, locally driven; and committed to welfare and security provision for normal citizens rather than political patronage for elites. This could possibly be achieved by a broad based power-sharing government that is guided by an explicit elaboration of socioeconomic rights, as originally referenced in the CPA. ${ }^{80}$ Typically, peace agreements do not tend towards such radical visions of

76 Comprehensive Peace Agreement, supra n 65 at Chapter III, Part I, Article 1.2.

77 McAuliffe, supra n 69 at 216.

78 Luke A. Patey, 'Crude Days Ahead? OIL and the Resource Curse in Sudan', African Affairs 109, no. 437 (2010): 617-36, https://doi.org/10.1093/afraf/adq043.

79 Alex de Waal, 'When Kleptocracy Becomes Insolvent: Brute Causes of the Civil War in South Sudan', African Affairs 113, no. 452 (2014): 349, https://doi.org/10.1093/afraf/adu028. Comprehensive Peace Agreement, supra n 65 at Chapter II, Part I, Article 1.6.1. 
social transformation, due to the relatively short span of a transition from war to postconflict. However, such a limited concept of transition and transformation neglects the myriad ways in which opportunities for economic power repeatedly present themselves in ordinary everyday politics. ${ }^{81}$ Finding the political will to implement such an equitable framework remains a significant challenge in South Sudan, however, given the extent to which political elites are implicated in this kleptocratic system. $^{82}$

Elsewhere, the CPA's provisions on security sector reform (SSR) and disarmament, demobilisation, and reintegration (DDR) processes did provide some transformative potential. Though SSR and DDR measures are not directly concerned with legal standards of accountability, they are often prerequisite-if not essentialto it. They may duly be regarded as part of the transitional justice framework, and are assessed as such herein. ${ }^{83}$ Indeed, de Waal has previously pointed to the transformative potential of SSR, arguing that ' $[\mathrm{w}]$ hen the security sector is exposed to democratic pressures, the political demand for SSR becomes a reality, and the space for reform exists. ${ }^{84}$ However, the CPA's SSR and DDR provisions maintained the agreement's state-centric focus, seeking to assert the legitimacy and authority of state institutions. This state-centric focus came at the expense of key local dynamics, which were repeatedly neglected despite their potential role in providing security and services in places where formal state institutions could not. ${ }^{85}$ de Waal identified the lack of local consultation in SSR in Sudan as 'a major missed opportunity' for conflict transformation. ${ }^{86}$ Another transformative opportunity spurned in the context of SSR was the CPA's joint integrated units. These were military units comprised of both the Sudanese military and the SPLM/A that would provide the nucleus of a national army if the referendum on southern self-determination confirmed unity. The parties made substantial progress on the integrated units between 2005 and 2011, but South Sudan's declaration of independence in July 2011 made their transformative potential moot.

Though almost 50,000 combatants were demobilised under the CPA, the process was largely a 'charade' whereby ' $\mathrm{t}$ ] he budget allocated was used,' 'individuals... received demobilisation benefits,' 'and reports of demobilisation were duly produced.' In reality, the number of soldiers increased after demobilisation as the parties moved to expand and consolidate their gains under the agreement. ${ }^{87}$ This reality reflects existing scholarship in the field, which notes a tension between SSR and DDR efforts and the concept of transitional justice. Where ex combatants are included in SSR and DDR processes, they can potentially resist or refuse future attempts to impose accountability, as in Sudan. Similarly, affording ex combatants

81 McAuliffe, supra n 69.

82 Leben Moro et al., 'Statebuilding and Legitimacy - Experiences of South Sudan' (United Kingdom: Secure Livelihoods Research Consortium, 2017), 22.

83 Chandra Lekha Sriram, 'Justice as Peace? Liberal Peacebuilding and Strategies of Transitional Justice', Global Society 21, no. 4 (2007): 579-86, https://doi.org/10.1080/13600820701562843.

84 de Waal, supra n 75 at 187-195.

85 Bennett et al., supra $\mathrm{n} 72$ at 145 .

86 de Waal, supra $\mathrm{n} 75$ at $187-195$.

87 Ibid. 
reintegration opportunities will seem grossly unfair to some victims, and can be construed as rewarding violence, as has also occurred in Sudan. ${ }^{88}$ Such phenomena cannot be reconciled with any concept of justice. In such situations, the clash between these paradigms is bypassed by applying only one of them. ${ }^{89}$

The CPA was an incredibly precise agreement, providing an ambitious political framework for transforming the relationship between Sudan and South Sudan. The agreement set out a formal and expansive institutional infrastructure through which power and wealth could be shared on a bilateral basis, allowing South Sudan to selfdetermine its political future. However, the CPA was merely a means of reframing the North-South conflict; not a way of transforming it. The agreement failed to achieve its vision of social, political and economic justice for all Sudanese, as the Forces for Freedom and Change (FFC) protests in April 2019 demonstrated. Could the CPA have affected a more transformative outcome? Had Sudan's other political parties and civil society organisations been included in negotiations, it is tempting to answer in the affirmative. The CPA was negotiated exclusively between the National Congress Party and the SPLM/A, with no input from women-even on the SPLM/ A side. Civil society organisations, in particular, may have anticipated the local concerns that fuelled intermittent conflict throughout Sudan in the aftermath of the $\mathrm{CPA}$, and diverted resources accordingly. For all its references to correcting injustice, inequality, and marginalisation, the CPA did little to consider these terms beyond its North-South axis, begging the question: justice for who? ${ }^{90}$

Though these criticisms impart valuable lessons about the negative effects of certain transitional mechanisms, their alternatives surmise the elusiveness of a perfect peace. Had negotiations involved a broader process of inclusion, they ran the risk of not producing any agreement at all. Aalen notes that attempts to include northern opposition parties in the initial IGAD negotiations in 1994 were a non-starter, while the attempt to consolidate several southern splinter groups into a viable political party under the Sudan Agreement in 1997 arguably did more harm than good to the prospects of lasting peace. ${ }^{91}$ Ultimately, the CPA produced a negative peace, marked by the periodic absence of war rather than the creation of transformative political and social practices. If Sudan and South Sudan are to escape their common history of conflict, transitional justice will not be enough. The peoples of Sudan and South Sudan must confront inequitable structures of power through a transformative approach that scrutinises the role that transitional mechanisms have played in maintain those structures in the past.

\section{SUDAN AND SOUTH SUDAN IN TRANSITION ONCE MORE}

A retroactive analysis of the Sudanese experience of transition is particularly relevant at this moment in time. Following Al Bashir's removal from office in April 2019, Sudan is facing a 'twin transition' from both authoritarianism and armed conflict. Africa: A Not so Obvious Relationship', African Affairs 108, no. 432 (2009): 453-73.

89 Vandeginste and Sriram, supra n 18 at 498.

90 Aldehaib, supra $n 48$.

91 Lovise Aalen, 'Making Unity Unattractive: The Conflicting Aims of Sudan's Comprehensive Peace Agreement', Civil Wars 15, no. 2 (2013): 176. 
Attempts to implement transformative change in such contexts are incredibly challenging. Of around 35 attempts at twin transitions since 1990, 'only a handful can be rated as successful in terms of at least ending conflict violence. ... ${ }^{92}$ Indeed, Natsios previously predicted that the kleptocratic, survivalist nature of $\mathrm{Al}$ Bashir's regime could make a post Bashir Sudan ungovernable, and a potential dissolution unmanageable. ${ }^{93}$ However, key political actors are too embedded in Sudan's neopatrimonial politics to simply fall away. Individuals such as General Mohamed Hamdan Dagalo (Hemeti) will be able to leverage political or military capital to buy back into the Sudanese political marketplace-a worrying trend that is particularly pervasive in Africa. ${ }^{94}$ It is worth reflecting on the extent to which the CPA propped up this neopatrimonial system as Sudan moves to transition towards a democratic state that can be relied upon for the provision of services and welfare. Pospisil notes that carefully negotiated transitional arrangements will be central to balancing the political capital of members of the old regime against the demands of the protest movement. ${ }^{95}$

A transformative approach informed by Sudan's experience of the CPA can augment the FCC's attempts to design the institutions that will transition Sudan from kleptocracy to democracy. Many of the FFC's demands are synonymous with the demands of transitional justice and its wider role in advancing democratization and maintaining peace and human security: negotiating an end to the armed conflicts in Darfur, South Kordofan and Blue Nile; revising the national constitution; and holding elections. ${ }^{96}$ Pospisil argues that the transition should proceed in that order, as it essential that the myriad armed groups participate in the transitional legal and political processes. ${ }^{97}$ Sudan's transition appears to hold much transformative potential: it is a grassroots movement that has united a highly competitive political system behind the goal of removing Al Bashir's regime. ${ }^{98}$ However, Sudan now finds itself at the beginning of a very challenging transitional process in which the move from violence is rarely linear but potentially chaotic, as violent clampdowns on popular protests in Khartoum attest. ${ }^{99}$ Particularly strong transitional provisions will be needed to restrict the Sudanese military's legitimate use of violence and transition the military to political forums for negotiation and dialogue. The use or threat of transitional justice as a means of impacting the balance of power between the FCC and the military may yet play an important role in this process. ${ }^{100}$

92 Jan Pospisil, 'Sudan's Enduring Transition: Evolving Arrangements after the Fall of Bashir', Spotlight Series (University of Edinburgh: Political Settlements Research Programme, 2019), 4, http://www.politi calsettlements.org/wp-content/uploads/2019/05/PA-X-Spotlight-Sudan-Digital.pdf: “. . .namely Nepal, Liberia, Sierra Leone (eventually), Mozambique in the early 1990s, and Kosovo as well as Bosnia Herzegovina (the last two involving extensive international military intervention).”

93 Natsios, supra n 50 at 200.

94 Denis M. Tull and Andreas Mehler, 'The Hidden Costs of Power-Sharing: Reproducing Insurgent Violence in Africa', African Affairs 104, no. 416 (2005): 375-98.

95 Pospisil, supra n 92.

96 Teitel, supra $\mathrm{n} 2$ at 2.

97 Pospisil, supra n 92.

98 Yasir Zaidan, 'How to Make Sudan's Revolution Succeed', Foreign Policy, 9 September 2019, https:// foreignpolicy.com/2019/09/09/how-to-make-sudans-revolution-succeed-hemeti-burhan-tmc/.

99 Bell, supra $n$.

100 Bell, supra n 56 at 90; cf. Cacciatori, supra n 67. 
Following the Revitalised Agreement on the Resolution of the Conflict in the Republic of South Sudan in September 2018, South Sudan now finds itself in a tentative post settlement transition. Understanding the CPA is central to managing the transition under the revitalised agreement, which recycles many of the CPA's flawed mechanisms. Power has once again been concentrated among the actors that dominated the political landscape before the South Sudanese civil war. However, patronage networks in South Sudan have been so exhausted and have become so factionalised that there no longer exists any distinct parties to lead a transformative peacebuilding/statebuilding project. ${ }^{101}$ The current peace deal shares power amongst a government-rebel dyad that is completely 'fictitious': most of the opposition leadership were part of the South Sudanese government or military prior to their dismissal by President Silva Kiir in December 2013. ${ }^{102}$ After five years of conflict, the 2018 agreement reinstates the status quo ante, returning political power to an elite cabal in Juba.

The concentration of power in the hands of a political elite has left little legitimate space for civil society groups and other parties to contest this power. As a result, violence remains a viable means of communicating grievance in the contested political space that divides centre and periphery in South Sudan. In orienting solutions around a government-rebel dyad, local actors have previously been encouraged to take up arms and align with one 'side' in order to have their grievances heard at the negotiating table. Ongoing efforts to resolve the conflict continue to incentivise this approach. This underscores the need for a transformative approach to the conflict in South Sudan. A state-centric approach has repeatedly neglected local concerns, causing peripheral regions to be drawn into the conflict in order to ensure that their grievances are heard. Recent efforts have also focused on the violence caused by the government-rebel conflict at the expense of the less visible forms of violence that South Sudanese experienced daily before the outbreak of civil war. ${ }^{103}$ These forms of violence must be confronted as part of a transformative vision of transitional justice.

Only a political process of broad based participation can address the local issues that will dictate the sustainability of the South Sudanese state, and these issues lie beyond the elitist contest for control of the centre. Policy makers have repeatedly called for a range of mechanisms to facilitate the inclusion of marginalised stakeholders in the statebuilding project, including a parliamentary executive, stronger federalist structures and a broadly constitutive process of national dialogue. Indeed, South Sudan's 'newness' has been repeatedly cited as an opportunity to experiment with innovative models of statebuilding. To date, top-down transitional approaches have favoured preservation of the status quo over radical redefinition of the South Sudanese state. Fundamentally, the country requires a 'reworking of the governance agreement between and within elites and communities if a negotiated settlement is

101 Nicki Kindersley and Øystein H. Rolandsen, 'Prospects for Peace and the UN Regional Protection Force in South Sudan', African Affairs, 2016, 12.

102 Lotje de Vries and Mareike Schomerus, 'South Sudan's Civil War Will Not End with a Peace Deal', Peace Review 29, no. 3 (2017): 335, https://doi.org/10.1080/10402659.2017.1344533. 
to lead to a sustainable peace. ${ }^{104}$ Only a transformative approach can negotiate these systems of governance from the ground up, and unleash the transformative dynamics necessary to achieve the CPA's vision of economic and social justice.

\section{CONCLUSIONS}

At its core, the CPA prescribed national level institutions that could transition-rather than transform - the North-South conflict into peaceful political spaces. In this respect, it was largely successful. The CPA provided forums for further negotiation and dispute resolution, ensuring a sustainable period of transition that secured a functioning GoSS in the wake of the agreement's conclusion. This proved crucial to forcing progress on other aspects of the agreement in the latter stages of the transition. The CPA thus successfully transformed the North-South armed conflict into a political one that the parties could challenge 'through the agreement's new institutional provision.' 105

Even with the provision of dispute resolution mechanisms, deadlock characterised the transition under the CPA. Disputes were referred up the dispute resolution hierarchy, but many were left unresolved due to deadlock within the Sudanese Presidency and the Political Commission. What is crucial, however, is that the parties did not resort to violence as a means of breaking this deadlock. Political negotiation and dialogue became normalised under the CPA, which managed to contain the violence and allowed a new political consensus to emerge. ${ }^{106}$ Previous peace agreements in Sudan failed to provide these channels of communication and negotiation, thus incentivising violence as a political bargaining tool and inviting their collapse. Though the CPA experienced setbacks as it wore on, its mechanisms arguably sustained the transition beyond the agreement itself. In this regard, it can be considered a success.

However, it must be remembered that transitional justice mechanisms do not resolve the conflict; they merely change the ways in which it is fought. Transitional mechanisms represent a political extension of the battlefield where the nature and direction of the transition remain contested. Whoever can win the transition can ultimately win the peace by directing the transitional mechanisms 'towards an end point for transition that approximates to the victor's battlefield goals. ${ }^{107}$ The Sudanese experience of transition exemplifies this. Over the course of the NorthSouth conflict, autonomy has been the principal vehicle for assuaging southern grievances. However, the ways in which the parties were able to control autonomy as a transitional vehicle had a significant impact on how southern self-determination played out in practice. Both the Addis Ababa and Sudan Peace Agreements were undone by Khartoum's ultimate control over the transitional infrastructure and the South's resulting inability to contest the direction of the transition. The CPA, in contrast, was the first North-South agreement to create a truly autonomous southern

104 International Crisis Group, 'South Sudan: A Civil War by Any Other Name', Africa Report (Addis Ababa/Juba/Nairobi/Brussels, 10 April 2014) (ii).

105 Bell, supra n 56 at 94 .

106 Bell, supra n 8.

107 Ibid. at 26. 
polity capable of forcing the issue southern self-determination when implementation of the agreement began to falter. In allowing the SPLM/A to contest its transitional mechanisms, the CPA ultimately delivered on the SPLM/A's political and military objective: an independent South Sudan. In doing so, the CPA secured transition but spurned transformation, as the enduring conflicts in Sudan and South Sudan attest.

Recent scholarship has flagged the need to move beyond analyses of transitional justice mechanisms and to focus on the bargaining processes that can compromise or capture transitional/transformative initiatives instead. ${ }^{108}$ Indeed, there is substantial overlap between the transformative analyses advanced herein and the 'political settlements' discourse, despite some apparent tension regarding the meaning of 'political settlement' in the context of transition. ${ }^{109}$ Kelsall has defined a political settlement as an agreement that ends conflict between powerful groups; that is oriented around a set of political institutions and a distribution of power; and is expected to deliver an acceptable distribution of benefits. In Kelsall's political settlements analysis, the focus should be on those actors with the ability to seriously disrupt, unsettle, or overturn the settlement. Such actors may have violent capability, king-making ability, or the capacity to mobilize en masse. In response, the political leadership may attempt to co-opt or repress these actors. Adopting Kelsall's framework, pre-CPA Sudan or contemporary South Sudan would not have a political settlement, as several powerful actors were/are trying to change the distribution of power, and were/are using violence to do so: '[T] here is not even a minimal agreement on rent distribution, let alone a common understanding or shared vision for society.' ${ }^{, 110}$

In contrast, Khan defines a political settlement as an 'interactive order,' where the settlement is the product of many interactions between actors, but is not based on any implicit or explicit agreement that can be identified ex ante. ${ }^{11}$ This distinction is important, as it helps to explain why an agreement on paper may function very differently in practice, and why similar agreements experience dissimilar outcomes in comparable contexts. For Khan, the way in which power is distributed becomes the most important factor in determining transformative change, which often takes place through new political mobilizations, economic opportunities, or external shocks; rather than social, cultural, or normative changes alone. ${ }^{112}$ Thus, while Kelsall's conceptualisation provides a useful framework for evaluating peace agreements and gauging the likelihood of sustainable peace accordingly, Khan's view of the political settlement more closely aligns with the transformative justice framework. Both frameworks seek to explore how transitional mechanisms intersect or inhibit other struggles regarding access to power and the nature of the state. This overlap is particularly pronounced when one considers how privileged discourses and formal institutions can be used to empower

Balasco, supra n 15; McAuliffe, supra n 13; McAuliffe, supra n 15.

109 Tim Kelsall, 'Towards a Universal Political Settlement Concept: A Response to Mushtaq Khan', African Affairs 117, no. 469 (1 October 2018): 656-69, https://doi.org/10.1093/afraf/ady018; Mushtaq H Khan, 'Power, Pacts and Political Settlements: A Reply to Tim Kelsall', African Affairs, 17 May 2018, https://doi.org/10.1093/afraf/ady019.

110 Kelsall, supra n 109 at 660.

111 Khan, supra n 109 at 671.

112 Mushtaq H Khan, 'Political Settlements and the Analysis of Institutions', African Affairs 117, no. 469 (2018): 636-55. 
elites at the expense of victims; or how socioeconomic rights and wealth sharing provisions can be used to prop up patrimonial structures. ${ }^{113}$ The link between transformative justice and political settlements discourse is duly deserving of further scholarly attention: indeed, this link may be central to translating transformative justice from an intellectual endeavour into a practicable theory of change. Without further investigation, the transformative turn in transitional justice literature only amounts to 'sloganeering, a guide to groping the dark. ${ }^{, 114}$

Nevertheless, current efforts to negotiate Sudan and South Sudan's transitions can learn much a retrospective analysis as advanced herein - indeed, in many ways, such efforts are bound up in the lessons of the past. To date, transitional processes prioritizing formal institutions in Sudan and South Sudan have neither attained a transformative vision of justice, nor curbed the use of a violence as a means to this end. Transformative change is most likely to take place at the local level where it can be informed by the local and particular needs of communities affected by legacies of violence. Neglecting this dynamic has allowed the South Sudanese civil war to spread to previously peaceful areas and 'draw in' local communities. Accordingly, peacebuilding efforts should prioritise popular access and participation in institutional design and implementation; encourage locally resonant mechanisms that resist international blueprints; and provide alternatives means to challenge structures of power at both the local and international levels. ${ }^{115}$

The Sudanese experience of transition provides an opportunity to interrogate the limits of transitional justice and the possibilities of transformative change. Though there has been limited knowledge transfer between the two, a transformative analysis is central to understanding conflict as cyclical - a particular characteristic of the conflicts in Sudan and South Sudan. However, a transformative approach also requires a 'reflexive awareness of the incompleteness of our understanding.' Academics and peacebuilders act on the basis of their own particular reading of a complex social system, not on the basis of superior scientific knowledge. Indeed, this is why transitional mechanisms play out so differently in different contexts, and why it is crucial that the link between transformative justice and political settlements discourse is further investigated. A transformative approach to institutional design must exercise due caution, as its consequences impact the everyday lives and livelihoods of people. ${ }^{116}$ Pospisil has urged such caution in the context of Sudan's contemporary transition, noting that transitional arrangements often become 'sticky' and remain well beyond their time. ${ }^{117}$ The legacy of the CPA-itself the basis of Sudan's 'transitional' constitution from the conclusion of the agreement in July 2005 to the ouster of Al Bashir in April 2019-remains an important and relevant example in this regard, and should be given due consideration.

Khan, supra n 112; McAuliffe, supra n 69; Jago Salmon and Catherine Anderson, 'Elites and Statebuilding', in Routledge Handbook of International Statebuilding, ed. David Chandler and Timothy D. Sisk, First issued in paperback (London: Routledge, 2015). 